\title{
Implementasi Sistem Daring (Dalam Jaringan) dan Luring (Luar Jaringan) dalam Pembelajaran Pendidikan Agama Islam
}

\author{
Sherliya Benita ${ }^{1}$, Wirdati², Edi Saputra ${ }^{3}$ \\ sherliyabenita1111@gmail.com¹, wirdati@fis.unp.ac.id ${ }^{2}$, edisaputra79@fis.unp.ac.id ${ }^{3}$ \\ Universitas Negeri Padang1,2,3
}

\begin{tabular}{|c|c|}
\hline ARTICLE INFO & \multirow{14}{*}{$\begin{array}{l}\text { This study aims to see how the online system and the } \\
\text { offline system in PAI learning in schools, especially in class X, } \\
\text { because at this time the world of education since the COVID } \\
19 \text { outbreak has experienced changes in the system and } \\
\text { implementation of learning that is different from the previous } \\
\text { one. This study aims to describe and answerthe problem being } \\
\text { researched which consists of the principal, two PAI teachers, } \\
\text { and } 15 \text { students. This research uses a qualitative method with } \\
\text { a case study approach. The researcher also uses a purposive } \\
\text { sampling data sampling technique, which is a sampling } \\
\text { technique where the researcher relies on his own judgment } \\
\text { when selecting members of the population to participate in his } \\
\text { research. The result of the research is that the implementation } \\
\text { of online and offline systems is currently carried out through } \\
3 \text { stages, namely planning, an implementation which includes } \\
\text { an opening, core, and closing activities, and the final stage, } \\
\text { namely evaluation. The implementation of learning during } \\
\text { the Covid-19 pandemic uses a different learning system, } \\
\text { namely using online learning applications such as WhatsApp } \\
\text { group, zoom, meet and google class. }\end{array}$} \\
\hline Article history: & \\
\hline Received, 21 Oktober 2021 & \\
\hline $\begin{array}{l}\text { Revised, } 29 \text { November } \\
2021\end{array}$ & \\
\hline $\begin{array}{l}\text { Accepted, } 28 \text { Februari } \\
2022\end{array}$ & \\
\hline Keywords: & \\
\hline Covid-19, Pendidikan & \\
\hline Agama Islam, Sistem & \\
\hline Pembelajaran, Daring, & \\
\hline Luring & \\
\hline Conflict of Interest: & \\
\hline & \\
\hline Fundir & \\
\hline None & \\
\hline
\end{tabular}

Corresponding Author: Sherliya Benita, Department Islamic Education Faculty of Social Science Universitas Negeri Padang, Indonesia, Email: sherliyabenita1111@gmail.com, Phone NO: +6282384178408

(c) (i) Copyright(C2022, Author(s)

\section{Pendahuluan}

Pandemi Covid-19 merupakan musibah yang memilukan seluruh penduduk bumi. Seluruh segmen kehidupan manusia di bumi terganggu, tanpa kecuali pendidikan. Banyak negara yang memutuskan menutup sekolah, perguruan tinggi maupun universitas, termasuk di Indonesia sendiri. Krisis benar-benar datang secara tiba-tiba, pemerintah di belahan bumi mana pun termasuk Indonesia harus mengambil keputusan yang pahit menutup sekolah untuk mengurangi kontak orang-orang secara masal dan untuk menyelamatkan hidup atau tetap harus membuka sekolah dalam rangka survive para pekerja dalam menjaga keberlangsungan ekonomi. Ada dua dampak dari keberlangsungan pendidikan yang disebabkan oleh pandemi Covid-19. 
Sherliya Benita, Wirdati, dan Edi Saputra : Implementasi Sistem Daring (Dalam Jaringan)...

Pertama adalah dampak jangka pendek, yang banyak dirasakan oleh banyak keluarga di Indonesia baik di kota maupun di desa, yang kedua jangka panjang yaitu merosotnya ilmu pengetahuan peserta didik di masa mendatang (Syah, 2020).

Dampak yang paling dirasakan oleh warga yang berada di desa, karena pembelajaran yang dilaksanakan di sekolah harus menggunakan jaringan yang kuat dan bagus, sedangkan banyak mereka yang desanya belum terjangkau oleh jaringan internet yang bagus, sehingga kasus-kasus kecelakaan banyak beredar di kalangan masyarakat seperti terjatuh dari atap rumah karena mencari jaringan, pergi ke bukitbukit yang terpencil agar bisa melangsungkan pembelajaran (Syah, 2020). Kondisi pendidikan di Sumatra Barat saat ini sedang mencanangkan program pembelajaran yang bisa dilaksanakan di sekolah-sekolah baik itu di desa maupun kota, karena beberapa daerah di Sumatera Barat ada zona merah yaitu kota Padang dan beberapa daerah zona Kuning seperti kota Solok, Tanah Datar dan juga beberapa kota lainnya, dan ada juga yang sedang berada di zona hijau seperti Lima Puluh kota sekitarnya (Padang Breaking News, Maret, 2020).

Pembelajaran daring merupakan pemanfaatan jaringan internet dalam proses pembelajaran. Adanya pembelajaran daring menjadikan peserta didik memiliki waktu belajar yang leluasa, peserta didik dapat belajar dimana pun dan kapan pun. Peserta didik dapat berinteraksi dengan guru melalui beberapa aplikasi yang sudah ada yaitu dengan aplikasi classroom, telepon atau live chat, zoom, maupun dengan melalui whatsapp group. Pembelajaran daring ini merupakan inovasi dan pendidikan untuk menjawab tantangan akan ketersediaan sumber belajar yang variatif. Pembelajaran sistem daring merupakan akronim dari "dalam jaringan". Pembelajaran daring juga salah satu metode pembelajaran online atau dilakukan melalui jaringan internet. Sistem pembelajaran ini dikembangkan oleh Kementrian Pendidikan dan Kebudayaan Republik Indonesia Terbuka dan Terpadu adalah merupakan program pemerintah dalam menjangkau pelajar skala nasional (Kementrian Pendidikan dan Kebudayaan RI, 2014: 1).

Pembelajaran sistem luring adalah pembelajaran yang menuntun guru untuk melaksanakan, sistem pembelajaran ini biasa dilakukan pada hari-hari biasanya sebelum terjadi pandemi COVID-19. Sistem luring atau luar jaringan ini di mana peserta didik bertatap muka secara langsung dengan guru serta peserta didik yang lainnya, namun pada saat pandemi ini muncullah istilah luring. Istilah luring adalah antonim dari kata daring. Dengan arti kata lain pembelajaran sistem luring telah diterapkan jauh sebelum adanya pandemi COVID-19, sehingga tidak asing lagi oleh peserta didik. Dalam keadaan menghadapi New Normal peserta didik dihadapkan dengan tantangan pembelajaran yang mana peserta didik dituntut untuk belajar sesuai dengan KD (Kompetensi Dasar) yang diprogramkan kepada peserta didik, sedangkan dalam keadaan normal saja, masih banyak pencapaian KD (Kompetensi Dasar) yang kurang optimal, apalagi dalam keadaan new normal ini, peserta didik dituntut untuk memahami pembelajaran dengan sistem daring. Dengan adanya sistem daring dan luring ini diharapkan mampu membantu dan meringankan peserta didik dalam mencapai materi pembelajarannya, di saat mereka tidak mengerti pelajaran sistem daring, mereka bisa menanyakan hal-hal tersebut waktu pelaksanaan pembelajaran luring (luar jaringan), untuk penggunaan istilah luar jaringan maka, untuk selanjutnya penulis menggunakan singkatan kata "Luring" (Syah, 2020). 
Pendidikan saat ini memasuki fase penerapan pembelajaran dengan dua sistem yaitu daring dan luring, sebagaimana yang telah kita ketahui bahwasanya pembelajaran daring adalah pembelajaran yang mengandalkan jaringan dan aplikasi yang bisa membantu dalam penyampaian materi pendidikan, sedangkan luring juga dimulai diterapkan di dalam kehidupan New Normal saat ini. Sekolah-sekolah yang berada di daerah zona hijau (zona aman) menerapkan pembelajaran dua sistem, yaitu tiga hari belajar secara daring dan tiga hari belajar luring dengan waktu yang diselangi, seperti satu hari belajar daring keesokannya belajar secara luring sampai begitu harihari berikutnya. Pada umumnya di Sumatera Barat sekolah SLTP dan SLTA sederajat telah menerapkan sistem pembelajaran daring dan luring, begitu pula dengan SMAN 1 Lubuk Basung yang telah menerapkan sistem pembelajaran daring dan luring sejak akhir bulan Desember 2020 lalu yang mengacu pada surat edaran yang keluar mengenai pembelajaran daring yang tertera dalam Undang-Undang nomor 55 tahun 2020. Beradasarkan pengalaman penulis sendiri yang telah melaksanakan PL (Praktek Lapangan) di SMAN 1 Lubuk Basung penulis telah melihat sendiri bagaimana karakteristik pembelajaran di sekolah tersebut, dan telah meperhatikan beberapa penerapan pembelajaran yang diajarkan oleh para guru-guru di sekolah menyikapi pembelajaran yang harus disampaikan meski harus dengan sistem dan media pembelajaran yang berbeda.

Berdasarkan observasi awal pengamatan yang telah dilakukan oleh penulis dari bulan Juli-Desember tahun 2020, dengan lingkungan dan sistem pembelajaran, SMAN 1 Lubuk Basung telah menerapkan terlebih dahulu sistem pembelajaran sistem daring dan luring ini, sehingga SMAN 1 Lubuk Basung bisa menjadi acuan dan gambaran bagi sekolah-sekolah lain untuk menerapkan pembelajaran sistem daring dan luring di sekolah-sekolah lain. Berdasarkan dari paparan di atas penulis tertarik untuk melaksanakan penelitian disana, dengan judul Implementasi Sistem Daring (Dalam Jaringan) dan Luring (Luar Jaringan) dalam Pembelajaran Pendidikan Agama Islam di SMAN 1 Lubuk Basung Kelas X".

\section{Tinjauan Pustaka}

Dalam Undang-undang Repoblik Indonesia Nomor 20 Tahun 2003 tentang tentang Sistem Pendidikan Nasional, bahwasannya pembelajaran adalah proses interaksi seorang guru dengan peserta didik dan sumber-sumber belajar yang berlangsung dalam suatu lingkungan belajar. Suatu Proses pembelajaran ditandai dengan adanya interaksi edukatif yang terjadi, maksudnya adalah interaksi yang secara sadar dengan adanya tujuan. Interaksi ini berasal dari tenaga pendidik (guru) dan proses belajar yang secara pedagogis pada diri peserta didik.

Menurut Trianto dalam jurnal Dasopang (2017), Pembelajaran adalah suatu aspek kegiatan yang lengkap dan tidak bisa dipaparkan seluruhnya. Secara lebih sederhananya adalah pembelajaran dapat diartikan sebagai produk interaksi yang saling berkaitan antara pengembangan dengan pengalaman hidup. Adapun menurut Hudojo, menyatakan bahwa suatu sistem pembelajaran dalam pandangan konstruktivitas memberikan perbedaan yang nyata. Ciri-cirinya adalah (a) siswa terlibat aktif dalam belajarnya, siswa belajar materi secara lebih mendalam dengan cara bekerja dan berfikir, dan (b) informasi atau berita baru harus dikaitkan dengan 
Sherliya Benita, Wirdati, dan Edi Saputra : Implementasi Sistem Daring (Dalam Jaringan)...

informasi sebelumnya, sehingga menyatu dengan pengetahuan yang dimiliki oleh peserta didik (Dasopang, 2017).

Pembelajaran memiliki beberapa prinsip yaitu: Pertalian, pembelajaran mudah berlaku bagi perkara-perkara yang mempunyai pertalian antara satu sama lain. Contohnya perihal-perihal yang sama, berkeselarasan dan berlaku dalam jarak masa yang singkat. Pengulangan, hal-hal yang sering kali diulang-ulang dapat membantu proses pembelajaran. Kepuasan, tindakan belajar yang menghasilkan akibat yang mendorong pembelajaran yang dipelajari akan mudah tinggal dalam ingatan. Pengalaman, pembelajaran dan kepahaman akan mudah diingat apabila peserta didik pernah mengalami sendiri kejadian tersebut. Motivasi, seseorang yang mendapatkan sebuah motivasi untuk belajar akan menghasilkan pembelajaran yang berkesan. Motivasi juga bisa berbentuk ekstrinsik (dari luar) maupun instrinsik (dari dalam) diri (Sihes, 2011).

Ahmad dalam jurnal Susanti (2017) Tafsir mendefenisikan Pendidikan Agama Islam adalah bimbingan yang diberikan oleh seseorang agar orang yang diajarkan dapat berkembang secara maksimal sesuai dengan ajaran Islam, dengan kata lain Pendidikan Agama Islam adalah bimbingan terhadap seseorang agar ia menjadi muslim semaksimal mungkin, muslim disini dimaknai dengan mengetahui semua ajaranajaran yang telah di jelaskan dalam kitab suci Al-Qur'an dan sunnah Rasulullah SAW. Ahmad Nasir menekankan sifat dari aktifitas Pendidikan Islam, yaitu berupa bimbingan sebagai suatu upaya yang tidak hanya ditekankan pada aspek pengajaran (transfer ilmu pengetahuan) tetapi juga arahan, bimbingan, pemberian petunjuk, dan pelatihan menuju arah terbentuknya pribadi muslim yang seutuhnya (Susanti, 2017).

Dalam kurikulum Undang-Undang Sisdiknas No. 20 Tahun 2003 Pasal 1 ayat 1, Pendidikan Agama Islam usaha sadar dan terencana untuk mewujudkan suasana belajar dan proses pembelajaran agar peserta didik secara aktif mengembangkan potensi dirinya untuk memiliki kekuatan spiritual keagamaan, pengendalian diri, kepribadian, akhlak mulia, serta keterampilan yang diperlukan dirinya, masyarakat, bangsa, dan negara. Pendidikan Agama Islam yaitu suatu usaha untuk membina serta mengasuh peserta didik untuk senantiasa berada dalam ajaran Islam secara menyeluruh, lalu menghayati tujuan, yang pada tujuan akhirnya dapat mengamalkan yang telah dipelajarinya. Mata pelajaran Pendidikan Agama Islam secara keseluruhannya dalam ruang lingkup Alquran, Hadis, Akidah Aklak, Fikih atau Ibadah dan Sejarah Kebudayaan Islam.

Daring merupakan singkatan dari istilah "Dalam Jaringan" menurut Moore, DicsonDeane \& Galyen (2011) pembelajaran daring adalah pembelajaran yang mengandalkan jaringan internet dengan aksebilitas, konektivitas, fleksibilitas dan kemampuan untuk memunculkan berbagai macam interaksi pembelajaran. Adanya wabah penyakit Covid-19 ini semua kegiatan yang mengundang kerumunan dan kegiatan yang dilangsungkan dengan melibatkan kontak dari manusia dengan manusia lainnya diberhentikan. Semua hal tersebut memiliki dampak pada ekonomi, sosial dan begitu juga dengan pendidikan. Dunia pendidikan terkhusus nya di Indonesia mengalami dampak yang sangat buruk, mulai diliburkannya semua sekolah dan pembelajaran 
dilangsungkan di rumah, sistem yang demikian tersebut yang dinamakan sistem online atau disebut juga dengan daring.

Luring merupakan singkatan dari "Luar Jaringan" atau sering juga disebut dengan pembelajaran yang dilakukan secara ofline. Kata "luring" merupakan lawan kata dari "daring", dengan demikian pembelajaran luring dapat diartikan sebagai bentuk pembelajaran yang sama sekali tidak terhubung dengan jaringan internet. Pembelajaran luring ini lebih mengandalkan kontak fisik secara langsung, baik itu guru dengan peserta didik, maupun peserta didik sesamanya. Pembelajaran luring juga mengandalkan 40\% kemampuan seorang guru dalam menerangkan dan memberikan materi pembelajaran, dalam proses pembelajaran luring ini, hal ini dikarenakan pembelajaran luring dapat dilihat secara langsung dan mengalami kontak fisik secara langsung pula, sehingga kita sebagai seorang guru akan langsung ditiru oleh peserta didik dalam proses pembelajaran, baik itu materi pembelajaran maupun sikap dan cara kita berperilaku.

Secara umum implementasi dalam kamus besar Indonesia berarti pelaksanaan atau penerapan. Sedangkan menurut istilah suatu implementasi biasanya terkait dengan suatu kegiatan yang dilaksanakan untuk mencapai tujuan tertentu. Implementasi merupakan suatu penempatan ide, inovasi, konsep, dan kebijakan suatu tindakan praktis sehingga dapat memberikan dampak, baik itu berupa perubahan pengetahuan, keterampilan maupun nilai dan sikap. Implementasi dari suatu kebijakan atau program, merupakan rangkaian pilihan yang bisa dilihat dari hubungan yang dibuat oleh badan dan pejabat pemerintahan yang dirangkum dalam bidang-bidang baik itu pendidikan, kesehatan maupun administrasi lainnya. Implementasi merupakan hal yang paling terpenting dari keseluruhan proses kebijakan dan merupakan bentuk upaya untuk mencapai tujuan tertentu dalam urutan waktu tertentu, dan pada dasarnya implementasi adalah upaya-upaya mencapai tujuan yang telah ditentukan dan tujuan program-program agar dapat memenuhi pelaksanaan kebijakan tersebut (Dunn, 2003).

Implementasi atau penerapan pembelajaran daring ini gencar diterapkan setelah adanya wabah penyakit Covid-19 yang membuat semua aktivitas apabila dilaksanakan dari rumah lebih baik dari pada melakukan aktivitas yang berada di luar perkarangan rumah yang melibatkan kerumunan sehingga mudahnya penyebaran virus Covid-19 ini. Di Indonesia pembelajaran daring sama hal nya dengan istilah pembelajaran jarak jauh (PPJ) yang melibatkan semua aplikasi yang berhubungan dengan sistem pembelajaran online. Pembelajaran daring resmi menjadi salah satu hal yang jitu untuk dilakukan saat Covid-19, pembelajaran daring ini dirancang sedemikian rupa agar mampu untuk tetap mengembangkan bakat dan minat sesuai dengan jenjang pendidikan yang tengah dijalani oleh peserta didik. Untuk penerapan itu semua perlunya kesiapan tenaga pendidik, kurikulum yang sesuai, kesediaan sumber belajar yang memadai serta dukungan jaringan yang stabil sehinga komunikasi peserta didik dengan gurunya dapat berjalan dengan lancar.

Implementasi dan penerapan sistem daring ini di Sumatera Barat sendiri juga secara menyeluruh menerapkan sistem daring, setelah ditetapkan oleh pemerintah untuk melangsungkan semua aktivitas belajar mengajar dilaksanakan di rumah. Pada tanggal 27 Agustus tahun 2020 kemarin yang dirangkum dalam berita PadangKita.com, yang mengabarkan bahwa pembelajaran daring telah resmi ditetapkan merata hampir seluruh kabupaten dan kota di Sumatera Barat menerapkan sistem pembelajaran 
Sherliya Benita, Wirdati, dan Edi Saputra : Implementasi Sistem Daring (Dalam Jaringan)...

daring. Dalam penerapan pembelajaran daring saat ini belum bisa dikatakan sepenuhnya ideal, karena masih banyak hambatan-hambatan yang dirasakan, baik itu bagi peserta didik maupun tenaga kependidikan itu sendiri. Hambatan-hambatan tersebut, sekaligus menjadi tantangan dalam pelaksanaan pembelajaran daring. Berdasarkan hasil wawancara dengan Ibu Dahlia Novela S.Pd.I ada beberapa langkahlangkah pembelajaran daring (dalam jaringan) dan luring (luar jaringan) adalah sebagai berikut:

Langkah-langkah pembelajaran daring

1. Guru mempersiapkan materi pembelajaran yang sesuai dengan silabus dan RPP (Rancangan Pelaksanaan Pembelajaran) yang telah dibuat.

2. Guru masuk dalam ruangan zoom class/whatsap group dengan menerapkan komponen-komponen dalam tahap penerapan pembelajaran yang pertama yaitu pembukaan, yang berisi salam pembuka dalam belajar, mengambil daftar hadir dan kegiatan pembukaan pembelajaran yang lainnya (kegiatan pembukaan).

3. Memberikan dan menerangkan materi pembelajaran (kegiatan inti).

4. Memberikan tugas ke peserta didik.

5. Menanyakan kepada peserta didik materi yang belum dimengerti.

6. Menyimpulkan dan menutup pembelajaran (kegiatan penutup).

Langkah-langkah pembelajaran luring.

1. Guru mempersiapkan materi pembelajaran yang sesuai dengan silabus dan RPP (Rancangan Pelaksanaan Pembelajaran) yang telah dibuat.

2. Guru memasuki ruangan kelas dengan mematuhi protokol kesehatan, begitu pun dengan peserta didiknya.

3. Guru juga menerapkan kegiatan pembukaan seperti salam pembuka, mengambil daftar hadir peserta didik, menanyakan materi pembelajaran sebelumnya (kegiatan kegiatan).

4. Memberikan dan mengajarkan materi pembelajaran kepada peserta didik.

5. Memberikan tugas kepada peserta didik (kegiatan inti).

6. Menanyakan materi yang belum dipahami oleh peserta didik.

7. Menyimpulkan dan menutup pembelajaran (kegiatan penutup).

Penerapan atau pengimplementasian sistem pembelajaran luring ini, dirasa sangat perlu untuk diterapkan, mengingat pada saat ini kita telah memasuki fase era New Normal, yaitu era kebiasaa baru. Dalam era New Normal ini semua kebiasan-kebiasaan baru mulai diterapkan oleh pemerintah, dan semua ketatanan kegiatan yang dilaksanakan di luar rumah diatur oleh pemerintah, yaitu di antaranya dengan memakai masker apabila keluar dari rumah, membawa handsanitizer kemanapun pergi dan menggunakannya selepas memegang benda benda yang umum di sentuh banyak tangan, serta menjaga jarak sejauh 1 Meter ketika mengobrol dengan lawan bicara, semua hal tersebut dinamakan menjaga protokol kesehatan. Dengan adanya aturan dan kebiasaan-kebiasaan yang mematuhi protokol kesehatan tersebut, pemerintah juga mencanangkan beberapa sekolah yang berada di daerah atau zona aman menerapkan sistem pembelajaran luring ini, karena adanya beberapa masalah dalam penerapan sistem daring, seperti terkendalanya jaringan, adanya beberapa peserta didik yang bertempat tinggal di daerah pelosok-pelosok yang masih minim 
jaringan internetnya di daerah mereka, menjadi alasan utama mengapa pembelajaran luring ini sangat perlu di terapkan.

\section{Metode}

Dalam melakukan penelitian ini penulis ingin memfokuskan perhatian pada implementasi pembelajaran sistem daring dan luring terhadap pembelajaran Pendidikan Agama Islam dengan menggunakan pendekatan atau penelitian kualitatif. Penelitian kualitatif adalah penelitian yang menghasilkan data sebuah penjabaran yang berupa sebuah kata-kata baik itu tertulis maupun lisan dari orang-orang dan perilaku yang dapat diamati (Margono, 2010:362). Penelitian deskriptif memiliki tujuan mendeskripsikan apa-apa yang saat ini berlaku. Penelitian ini tidak bertujuan untuk menguji hipotesis dan tidak pula menggunakan hipotesis, namun hanya mendeskripsikan informasi apa adanya sesuai dengan variable (Mardalis, 1990: 26).

Penelitian kualitatif deskriptif adalah jenis penelitian yang menggunakan metode pengumpulan data berupa gambar, kata-kata atau ucapan dari orang-orang serta perilaku yang dapat damati dan bukan berupa angka-angka atau data statistik. Berdasarkan penelitian di atas peneliti model kualitatif bermaksud untuk menjelaskan peristiwa-peristiwa dan kejadian-kejadian yang terjadi pada saat penelitian dilakukan. Adapun alasan penulis menggunakan jenis penelitian kualitatif ini adalah data yang dihasilkan dari penelitian ini berupa data deskriptif yang bersumber dari hasil observasi, wawancara, dan dokumentasi. Penelitian ini menjelaskan serta mendeskripsikan realita atau fakta di lapangan mengenai implementasi sistem daring dan luring terhadap pembelajaran Pendidikan Agama Islam di SMAN 1 Negeri Lubuk Basung kelas X tahun ajaran 2020/2021.

\section{Hasil dan Pembahasan}

\section{Perencanaan Implementasi Sistem Daring (Dalam Jaringan) dan Luring (Luar Jaringan) Dalam Pembelajaran Pendidikan Agama Islam di SMAN 1 Lubuk Basung.}

Dalam sebuah implementasi tentu ada sebuah perencanaan yang dibutuhkan, agar dalam penerapan tersebut kegiatan yang kita lakukan bisa lebih terstruktur dan terarah. Untuk menghasilkan pembelajaran yang diinginkan dan meefisienkan waktu pembelajaran maka sebuah pembelajaran diperlukannya perencanaan. Perencanaan yang baik, akan menghasilkan sebuah pembelajaran yang baik pula, begitu pula sebaliknya jika perencanaan dalam sebuah pembelajaran tidak baik, maka pelaksanaan dan hasilnya juga tidak baik. Pada saat sekarang ini dan dalam kondisi pandemi Covid-19 sebuah pembelajaran dan sistemnya tentu tidak akan sama dengan pembelajaran sebelumnya. Untuk mempersiapkan pembelajaran saat pandemi ini para guru ditantang untuk merencanakan pembelajaran, bagaiamana caranya pembelajaran itu bisa tersampaikan makna dan tujuannya bisa tercapai saat di implementasikan kepada peserta didik. Meskipun pada saat ini tidak ada RPP (Rancangan Pelaksanaan Pembelajaran) yang kushus untuk penerapan pembelajaran di situasi pandemi, namun guru harus bisa menyampaikan materi pembelajaran yang dapat dipahami oleh peserta didik dan juga bisa diterapkan oleh peserta didik dalam kehidupan sehari-hari.

\section{Perencanaan}


Sherliya Benita, Wirdati, dan Edi Saputra : Implementasi Sistem Daring (Dalam Jaringan)...

Perencanaan adalah langkah awal dalam mempersiapkan sebuah proses pembelajaran. Dalam kondisi daring ini tata cara mempersiapkan pembelajaran baik itu silabusnya, RPP (Rancangan Pelaksanaan Pembelajaran), media pembelajaran sama dengan pembelajaran luring, hanya saja hal yang membedakannya adalah model atau media pembelajarannya yang berbeda, oleh karena itu perlunya seorang guru mempersiapkan apa-apa saja yang akan diberikan kepada peserta didik. Perencanaan, pembelajaran sistem luring juga memiliki perencanaan, seperti RPP, Model pembelajaran, dan lain hal sebagainya, namun perbedaan perencanaan daring dengan luring adalah mempersiapkan kegiatan tatap muka, jadi perencanaannya sampai berupa kegiatan pembuka, inti, dan penutup (Qasim, 2016).

\section{Pelaksanaan}

Dalam melaksanakan pembelajaran sistem daring, guru melaksanakan apa-apa yang telah dipersiapkan ditahap perencanaan, melaksanakan RPP yang dirancang, model pembelajaran yang disiapkan dan metode yang telah dirancang. Cara penyampaian pembelajaran daring melalui media aplikasi whatsapp dan zoom class. Pelaksanaan, sistem luring pelaksanaannya sudah umum, seperti pembelajaran sebelum-sebelumnya yang sudah dilakukan guru sebelum wabah Covid-19 menyerang. Namun bedanya sekarang adalah penerapan pembelajaran menggunakan protokol kesehatan dan jam pembelajarannya dikurangkan 15 menit dari jam pelajaran biasanya (Febrina, 2018).

\section{Evaluasi}

Evaluasi adalah suatu proses yang dilakukan baik itu dalam pembelajaran maupun dalam sebuah kegiatan apapun perlu adanya evaluasi, evalusi bertujuan sebagai ajang dari perbaikan untuk kegiatan-kegiatan atau proses pembelajaran selanjutnya, evaluasi ini juga mencakup 3 inti yaitu evaluasi perencanaan, evaluasi pelaksanaan dan evaluasi hasil atau nilai pembelajaran. Evaluasi dapat mendorong siswa untuk lebih giat belajar secara terus menerus dan juga mendorong guru untuk lebih meningkatkan fasilitas dan kualitas belajar siswa. Dalam pembelajaran sistem daring (dalam jaringan) evaluasi yang dilakukan adalah bagaimana materi pembelajaran apakah bisa di sampaikan melalui media online dan apa saja kekurangan-kekurangannya. Dalam evaluasi pembelajaran luring (luar jaringan) banyak hal yang perlu diperhatikan karena dengan memperbaiki hal-hal yang kurang dalam penerapan pembelajaran luring (luar jaringan) akan merubah sistem pembelajaran yang lebih baik lagi untuk kedepannya (Mahirah, 2017)

\section{Skema Pembelajaran Daring (Dalam Jaringan) dan Luring (Luar Jaringan)}

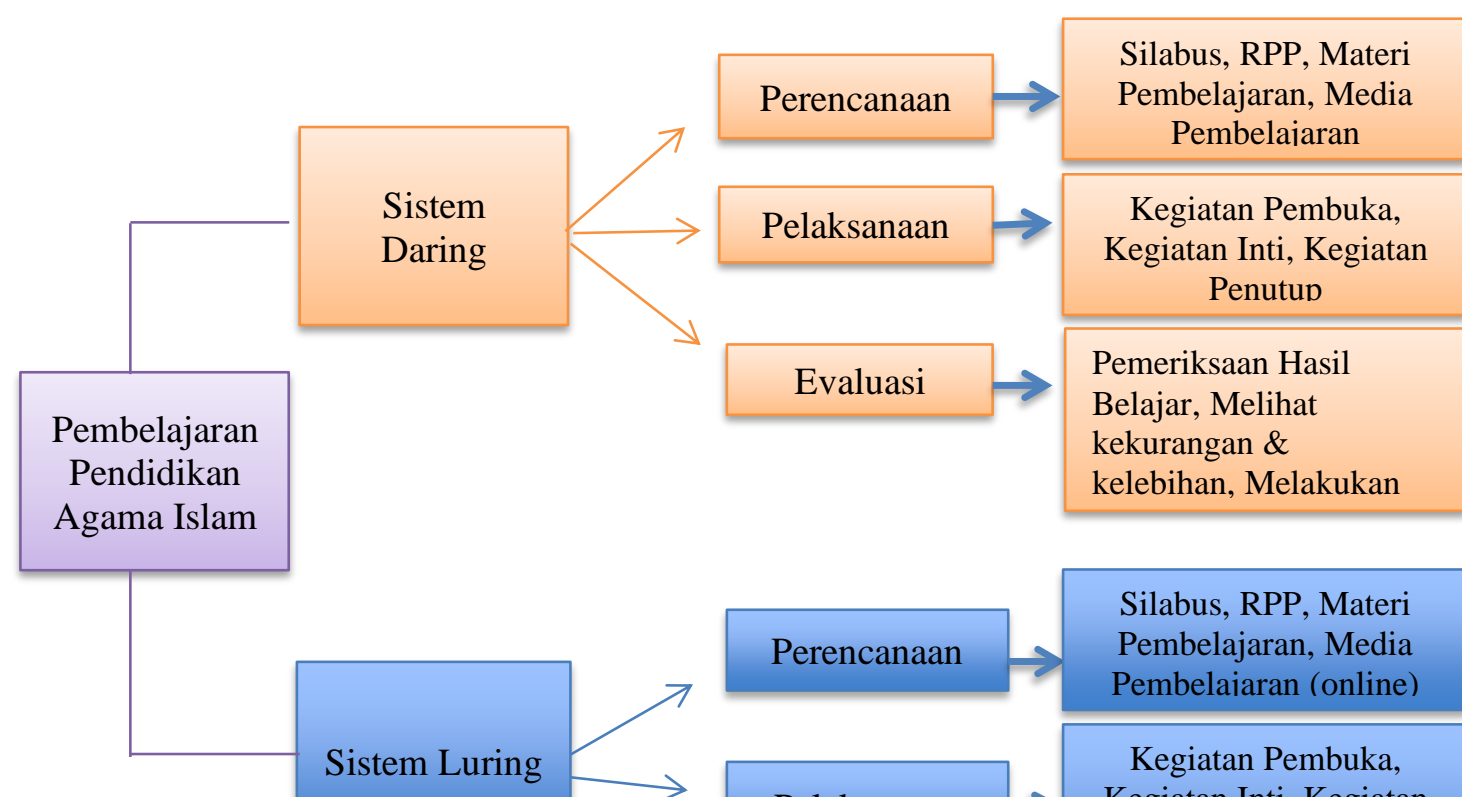


Dalam tahap perencanaan peneliti sudah melakukan wawancara dengan dua orang guru Pendidikan Agama Islam Kelas X di SMAN 1 Lubuk Basung, hasil wawancara dengan Bu Dahlia Novela, S.Pdi (wawancara 25 Agustus 2021) adalah:

"Untuk sistem daring, perencanaan ibuk adalah dengan mempersiapkan atau memberitahukan kepada peserta didik satu hari sebelum dilaksanakan pembelajaran untuk mempelajari materi yang akan dipelajari besok hari, dan mempersiapkan videovideo pembelajaran yang terkait materi pembelajaran serta mempersiapkan media pembelajaran berupa PPT (Power Point), terkadang juga menggunakan zoom meeting, sedangkan pembelajaran luring (luar jaringan) pesiapannya sama dengan sistem pembelajaran sebelumnya menerapkan RPP (Rancangan Pelaksanaan Pembelajaran) yang telah di rancang dan juga mempersiapkan media pembelajaran berupa modul pembelajaran."

Kemudian perencanaan dalam pembelajaran yang dilakukan oleh guru PAI lainnya yaitu Ibu Iza Asmara S.Pdi (wawancara 25 Agustus 2021) dalam melaksanakan pembelajaran adalah:

"Perencanaan yang dilakukan terhadap materi pembelajaran tentu sama antara daring (dalam jaringan) dan luring (luar jaringan) namun cara penyampaiannya saja berbeda, untuk cara penyampaian pembelajaran yang daring (dalam jaringan) dengan Ibu memberikan materi pembelajaran melalui zoom meeting, melalui grup wa, nah untuk melaksanakannya Ibu juga mempersiapkan link zoom meeting satu hari sebelum masuk kelas, merangkum materi pembelajaran berbentuk video, dan juga menerapkan materi pembelajaran sesuai RPP (Rancangan Pelaksanaan Pembelajaran) yang telah di buat. Sedangkan untuk persiapan pembelajaran luring (luar jaringan) Ibu lebih memfokuskan pada penerapan pembelajarannya keadaan siswa, jadi perencanaan Ibu hanya kepada pemahaman materi yang diajarkan besok jikalau ada peserta didik yang kurang jelas/paham dengan pembelajaran yang diajarkan, dalam merencanakan pembelajaran luring (luar jaringan) Ibu melakukannya sesuai dengan RPP (Rancangan Pelaksanaan Pembelajaran) pula, jadi semuanya bisa teratur dan terstruktur."

Dalam tahap perencanaan pelaksanaan pembelajaran dikontrol juga oleh Bapak kepala sekolah yang di tuturkan langsung dalam wawancara bersama Drs. Muhamad Mustapa Kamil selaku kepala sekolah SMAN 1 Lubuk Basung (wawancara 25 Agustus 2021) adalah:

"Untuk pengawasan tentu pasti bapak lakukan, namun dalam pembelajaran daring (dalam jaringan) saya agak terkandala dengan pengontrolannya karena begitu banyak grup-grup belajar peserta didik ini, namun saya terus melakukan pemantauan melalui guru mata pelajaran, namun untuk sistem pembelajaran luring (luar jaringan) saya bisa mengkoordinasi secara langsung dengan datang ke sekolah." 
Sherliya Benita, Wirdati, dan Edi Saputra : Implementasi Sistem Daring (Dalam Jaringan)...

Setelah melaksanakan wawancara dengan guru mata pelajaran PAI dan kepala sekolah SMAN 1 Lubuk Basung, penulis bisa menyimpulkan bahwa dalam perencanaan implementasi sistem daring (dalam jaringan) dan luring (luar jaringan) dalam pembelajaran PAI, penerapan antara sistem daring (dalam jaringan) dengan sistem luring (luar jaringan) tidak jauh berbeda, namun yang membedakannya adalah cara pelaksanaannya, namun walaupun demikian ada hal-hal yang membedakannya seperti saat perencanaan daring (dalam jaringan) guru mempersiapkan hal-hal seperti link zoom meeting, power point, dan rangkuman materi yang akan diajarkan kepada peserta didik, sedangkan perencanaan pembelajaran luring (luar jaringan) perencanaan pembelajarannya sesuai dengan RPP (Rancangan Pelaksanaan Pembelajaran), KD (Kompetensi Dasar) KI (Kompetensi Inti) dan silabus yang telah disiapkan, namun dalam pembelajaran luring (luar jaringan) tidak lupa juga mempersiapkan protokol kesehatan dan mematuhi aturan-aturan dari pemerintahan.

\section{Pelaksanaan Implementasi Sistem Daring (Dalam Jaringan) dan Luring (Luar Jaringan) Dalam Pembelajaran Pendidikan Agama Islam di SMAN 1 Lubuk Basung.}

Tahapan selanjutnya dalam sebuah pembelajaran adalah pelaksanaan. Dalam implementasi sistem daring (dalam jaringan) dan luring (luar jaringan) dalam pembelajaran Pendidikan Agama Islam di SMAN 1 Lubuk Basung, guru-guru mata pelajaran PAI memiliki caranya masing-masing. Berdasarkan hasil wawancara dengan Ibu Dahlia Novela S. Pdi sebagai guru mata pelajaran PAI kelas X SMAN 1 Lubuk Basung (wawancara tanggal 25 Agustus 2021) yaitu:

"Untuk sistem pembelajaran daring (dalam jaringan) pelaksanaannya dengan cara masuk kedalam grup kelas dan mengajar serta menjelaskan materi pembelajaran hari itu, lalu memberikan tugas kepada peserta didik, lalu menampilkan media pembelajaran yang telas dipersiapkan, kemudian kegiatan menyimpulkan pembelajaran terakhir kegiatan penutup, biasanya materi yang telah diberikan waktu daring akan dipraktekkan atau diterapkan di pembelajaran sistem luring (luar jaringan) sedangkan pembelajaran secara luring (luar jaringan) untuk tahap pelaksanaannya sama dengan melaksanakan pembelajaran tatap muka sebelum ada pandemi COVID-19, namun hal yang membedakannya adalah dalam melaksanakan pembelajaran luring (luarjaringan) waktu pelaksanaan pembelajarannya dikurangkan dari 1 jam nya 45 menit sekarang menjadi 30 menit saja, yang biasanya 1 kelas berjumlah kurang lebih 30-35 orang sekarang menjadi 15-17 dan hal yang terpenting saat melaksanakan pembelajaran luring yaitu mematuhi pratokol kesehatan."

Selanjutnya tahapan pelaksanaan pula oleh Ibu Iza Asmara S. Pdi guru mata pelajaran PAI kelas X di SMAN 1 Lubuk Basung (wawancara 25 Agustus 2021) yaitu:

"Penerapan atau pelaksanaan yang Ibu lakukan kepada pembelajaran sistem daring (dalam jaringan) yaitu dengan cara memasuki kelas melalui grup whatsapp dan melakukan tahap pembukaan berupa salam, menanyakan kabar peserta didik, mengambil absensi, menanyakan pembelajaran minggu sebelumnya tahapan selanjutnya adalah tahapan inti yaitu memberikan dan menjelaskan materi pembelajaran berbentuk power point, ada yang berbentuk video dan media lainnya, lalu ibu akan memberikan tugas tahapan terakhir dalam pembelajaran adalah penutup ibu akan menimpulkan pembelajaran hari itu dan menanyakan kepada peserta didik mengenai apa yang belum dia paham, serta mengingatkan peserta didik memahami 
pembelajaran untuk minggu selanjutnya. Untuk pembelajaran luring (luar jaringan) perlakuannya sama dengan sistem daring, karena pembelajaran daring (dalam jaringan) dan luring (luar jaringan) dilakukan secara bersamaan di waktu yang bersaaman pula yang daring (dalam jaringan) melalui jaringan sedangakan yang luring (luar jaringan) secara tatap muka langsung, untuk itu pelaksanaan luring saat ini tidak jauh berbeda dengan pembelajaran sebelum adanya pandemi COVID-19, yaitu masuk kelas dan menerangkan pembelajaran kemudian memberikan tugas."

Berdasarkan hasil kedua wawancara dengan guru mata pelajaran PAI datas maka penulis dapat menyimpulkan tahap pelaksanaan sistem daring (dalam jaringan) dan luring (luar jaringan) di SMAN 1 Lubuk Basung adalah untuk pelaksanaan daring (dalam jaringan) pelaksanaannya menggunakan jaringan internet dan melalui media media online seperti whatsapp grup, zoom meeting, youtube, dan aplikasi yang bisa mendukung belajar secara online/daring dan dalam mengimplementasiannya sama tahapannya dengan belajar tatap muka, materi nya tetap sesuai dengan silabus, KD (Kempetensi Dasar), KI (Kompetensi Inti), RPP (Rancangan pelaksanaan Pembelajaran) yang telah dirancang dan dipersiapkan, tetapi materi pembelajaran untuk daring (dalam jaringan) diberikan atau diajarkan dalam bentuk sebuah video ataupun power point lalu peserta didik bisa belajar dan mengerti pembelajaran walaupun hanya berada di rumah saja. Sedangkan pembelajaran luring (luar jaringan) dilaksanakan dengan cara datang ke sekolah dengan peserta didik yang dibagi pershift dan waktu pelajarannya yang dipersingkat dari 45 menit perjam pelajaran menjadi 30 menit perjam pelajarannya dan tentunya mematuhi pratokol kesehatan. Untuk tahapan pembelajaran luring (luar jaringan) ada 3 pula yaitu tahapan pembuka yang mana guru membuka pelajaran dengan salam, mengabsen peserta didik dan menanyakan materi pelajaran sebelumnya, kemudian tahapan inti yaitu guru memberikan dan mengajarkan materi pembelajaran, lalu peserta didik di berikan tugas, dan tahapan terakhir yaitu tahapan penutup yaitu guru menyimpulkan materi pembelajaran dan menanyakan kepada peserta didik materi yang belum dimengerti dan diakhiri dengan do'a dan salam penutup.

\section{Evaluasi Implementasi Sistem Daring (Dalam Jaringan) dan Luring (Luar Jaringan) Dalam Pembelajaran Pendidikan Agama Islam di SMAN 1 Lubuk Basung.}

Tahapan terakhir dari sebuah implementasi sitem daring (dalam jaringan) dan luring (luar jaringan) dalam pembelajaran PAI di SMAN 1 Lubuk Basung yaitu sebuah evaluasi. Berdasarkan hasil wawancara dengan guru mata pelajaran PAI kelas X Ibu Dahlia Novela S. Pdi (wawancara 25 Agustus 2021) sebuah evaluasi pembelajaran yang beliau lakukan adalah:

"Dalam melaksanakan pembelajaran tentu ada evaluasi, evaluasi yang Ibu lakukan sekali satu minggu, yaitu di hari sabtu Ibu mengoreksi kembali satu persatu apa-apa saja materi pelajaran yang belum tersampaikan dan terlaksana belum efektif rasanya, maka Ibu akan merancang kembali dan mempersiapkannya secara matang lagi, dengan kemungkinan besar menukar metode-metode pembelajaran yang dirasa cocok diterapkan di kelas tersebut. Untuk evaluasi sistem daring (dalam jaringan) Ibu biasanya sepulang sekolah mengecek kembali di grup whatsapp peserta didik yang belum mengirimkan tugas, materi yang rasanya belum tersampaikan juga secara online dan ada juga beberapa kelas online yang tertinggal karena terkendala terbagi fokus mengajar yang daring (dalam jaringan) dengan mengajar luring (luar jaringan) 
Sherliya Benita, Wirdati, dan Edi Saputra : Implementasi Sistem Daring (Dalam Jaringan)...

sehingga menyebabkan tidak masuk kelas dan tidak menyampaikan materi pembelajaran, hal-hal seperti yang terjadi tersebut adalah sebuah evaluasi yang Ibu coba akan memperbaikinya untuk pembelajaran minggu-minggu berikutnya."

Selanjutnya evaluasi dalam pembelajaran juga dikemukakan oleh Ibu Iza Asmara S.Pdi selaku guru mata pelajaran PAI kelas X di SMAN 1 Lubuk Basung (25 Agustus 2021) yang hasilnya yaitu:

"Untuk tahapan evaluasi, Ibuk melaksanakannya dengan cara setelah pulang dari sekolah, Ibuk akan mengecek kembali pembelajaran yang diberikan kepada peserta didik apakah ada peserta didik yang tidak mengerjakan tugasnya, apakah ada yang tidak mengumpulkan tugas. Jika peserta didik tidak mengerjakan atau mengumpulkan tugasnya, maka peserta didiknya akan ditegur lalu kemudian jika tidak ditanggapi, maka peserta didiknya akan dipanggil ke sekolah untuk ditanyakan masalah dan kendala yang dihadapinya ketika sedang membuat tugas/alasannya kenapa tidak membuat tugas. Untuk evaluasi pembelajaran, jika belum tersampaikan dengan sepenuhnya maka Ibuk akan mencari jam kosong untuk menyampaikan materi pembelajaran untuk solusi dari kekurangan materi yang disampaikan sebelumnya."

Dari hasil wawancara dengan kedua guru mata pelajaran PAI di SMAN 1 Lubuk Basung mengenai tahap evaluasi dalam pembelajaran, penulis dapat menyimpulkan bahwa tahapan evaluasi dalam implementasi sistem daring (dalam jaringan) dan luring (luar jaringan) di SMA N 1 lubuk basung adalah dengan cara guru meluangkan waktunya sepulang sekolah untuk mengecek kembali materi yang telah disampaikan apakah sudah maksimal, apakah peserta didiknya hadir lengkap atau ada yang tidak hadir, sampai kepada pengecekkan tugas, apakah tugasnya dikerjakan atau tidak, hal itu dilakukan baik untuk pembelajaran secara daring (dalam jaringan) maupun secara luring (luring), jika ada peserta didik yang tidak melaksanakan tugasnya maka di berikan teguran kepada peserta didik tersebut, jika masih tidak dihiraukan maka peserta didik diberikan surat pemanggilan agar datang kesekolah untuk ditanyakan apa penyebabnya tidak mengerjakan tugasnya hal ini tentunya memnuhi protokol kesehatan, dan solusi ini diharapkan bisa memaksimalkan proses pembelajaran.

\section{Simpulan}

Perencanaan adalah tahap pertama dari sebuah implementasi pembelajaran, baik itu pembelajaran daring (dalam jaringan) dan Pembelajaran sistem luring (luar jaringan). Perencanaan dalam pembelajaran dipersiapkan oleh guru, perencanaan yang dilakukan adalah mempersiapkan bahan ajar yang sesuai dengan RPP (Rancangan Pelaksanaan Pembelajaran), silabus, dan bahan pembelajaran yang lainnya, agar sebuah pembelajaran bisa dilaksanakan dengan sebaik mungkin.

Pelaksanaan pembelajaran sistem daring (dalam jaringan) saat sekarang ini dilaksanakan melalui online yang mengandalkan jaringan internet, guru menyampaikan pembelajaran kepada peserta didik melalui grup whatsapp dengan guru dan peserta didik berada di rumah masing-masing. Sedangkan pembelajaran sistem luring (luar jaringan) dilakukan sama hal nya dengan pembelajaran sebelum adanya wabah COVID-19 yang pembelajarannya dilakukan secara tatap muka dengan memenuhi protokol kesehatan. Evaluasi pembelajaran sistem daring (dalam jaringan) dan luring (luar jaringan) dilakukan setelah dilaksanakannya kedua sistem tersebut. 


\section{Referensi}

Dasopang Muhammad Darwis. 2017. Belajar dan Pembelajaran. Fitrah. Vol. 03. No. 2.

Dunn Muhammad. 2003. Pengertian Implementasi. hal 109.

Febrina Dilla. 2018. Studi Tentang Pelaksanaan Pembelajaran Geografi Berdasarkan Standar Proses di SMA Negeri 7 Padang. Universitas Negeri Padang.

Halal Rizqon Syah Aji. 2020. Dampak Covid-19 pada Pendidikan di Indonesia: Sekolah, Keterampilan, dan Proses Pembelajaran. Jurnal Sosial dan Budaya Syar-i FSH UIN Syarif Hidayatullah Jakarta, Vol. 7 No. 5.

Mahirah. 2017. Evaluasi Belajar Peserta Didik (Siswa). UIN Alauddin Makasar. Vol 1. No 2.

Mardalis. 1990. Metode Penelitian Suatu Pendekatan Proposal. Jakarta: Bumi Aksara.

Margono. 2010. Metode Penelitian Pendidikan. Jakarta: Rineka Cipta.

Qasim Muhammad. 2016. Perencanaan Pengajaran Dalam Kegiatan Pembelajaran. UIN Alauddin Makasar. Vol 3.

Sihes Johari Ahmad. 2011. Konsep Pembelajaran. Fitrah. Vol 02. No 01.

Susanti Desi. 2017. Pengembangan Pendidikan Agama Islam. Edureligia. Vol 1. No. 02. 